\title{
EVALUATE THE EFFECTIVE RESOURCE MANAGEMENT THROUGH PERT ANALYSIS
}

\author{
Aditi S. Baghele $^{1}$, P. P. Bhangale ${ }^{2}$, Prafulla Wankhede ${ }^{3}$ \\ ${ }^{1}$ Assistant Prof, Department of Civil, SSGB College Engineering \& Technology Bhusawal, Maharashtra, India \\ 425203 , \\ ${ }^{2}$ Associate. Prof, Department of civil, SSGB College Engineering \& Technology Bhusawal, Maharashtra, India \\ 425203 , \\ ${ }^{3}$ Assistant Prof, Department of Civil, SSGB College Engineering \& Technology Bhusawal, Maharashtra, India \\ 425203 ,
}

\begin{abstract}
Now a day's mass housing construction projects are common in India. There are so many approaches have been used for repetitive construction projects towards optimizing time and cost. In this project we have implemented a proposed theoretical model for effective utilization of labour to get optimum duration and cost. Generally critical path method is used for repetitive type of construction but in this project we use programme evaluation review technique to find the duration of project. There are many resources which affect the project time and cost like material, money, machinery, space etc. But from the literature survey it is observed that now a day's the labour is major resource which affects the productivity of project. Labour absenteeism rate is about $5 \%$ to $25 \%$ in construction projects, which is vary according to the size of projects. There are so many factors affecting the labour absenteeism. The study of these factors is necessary because by studying these factors we get an idea about the labours problems. Once we know about the labour problems we can solve their problems, we can provide a various facilities by which labours get satisfied. So in this way we can reduce the absenteeism rate of labours by solving their problems and by providing good facilities to them. The goal of any construction project is to complete the project within the estimated time and with minimum cost. The delay in a construction projects affects both owner and contractor. The main goal of this study is to find out the optimum duration for the completion of project. Because we know that if the project duration is minimum then project cost is automatically reduces. In this project the data is collected from the mass housing construction project. The expected time for the completion of project is finding out by using the programme evaluation review technique. Now the collected data is analysed and find out the optimum duration and cost. We know that the construction industry is a second largest industry in a world. The development of such industry plays an important role in a developing country like India. So for that it is necessary to improve the productivity of construction industry
\end{abstract}

Keywords: resource management, productivity, mass housing construction, construction industry

\section{INTRODUCTION}

Generally critical path method (CPM) is used for repetitive types of projects where the time estimates for various activities are either known or can be determined fairly accurately. We know that PERT is used for pioneering type of projects i.e. projects which are the first of their own kind and where prior data about activity times is not available. But in this study we use Programme Evaluation Review Technique for the repetitive type of projects i.e. Mass Housing construction projects. The time duration to complete the project is finding by using the PERT. There are five types of resource management. But, in the case of repetitive activities of the project, manpower, and machineries are the major resources which influence the project schedule. After studying so many papers I observed that because of inefficient management of labour the productivity of the project is badly influenced, i.e. manpower are the major recourses which influence the project duration as compare the machineries. Therefore in this study we used the manpower management to improve the productivity of project. In recent year mass housing projects are more common in construction industry. Since mass housing projects have high repetitive activities, these projects are more concern with the problems relating to the allocation of resources in scheduling. Moreover most of the contractors are forced to schedule the project with deadline as per the Clint requirements. Schedule for the smooth movement of resource will minimize the idle time and the total project cost. And total project cost and time reduce means productivity improves. If we did labour management properly definitely we can improve the productivity of project.

\section{LITERATURE REVIEW}

The literature survey conducted gives a conclusion that in most countries, labour cost comprises 30 to $50 \%$ of the overall project's cost. There are many challenges that are faced by construction industry in India, but one of the important challenges is labour productivity in construction. Now a day's labour problem becomes a major problem in 
construction industry as well as other field. Hence manpower has an important role in construction. While doing project management, if we did the proper manpower management the total project cost would be reduced. So we have to improve the labour productivity.

There are so many factors that affect the labour productivity which are studied in literature survey, and in this survey we observed that labour absenteeism is major problem. The effective utilization of labour gives the effective cost reduction for the entire project. There are so many methods are adopted to reduce the project duration or to get the optimum solution.

\section{STUDY OF RESOURCE MANAGEMENT AND NETWORK TECHNIQUES}

In this project we use a new approach for the labour management or we can say that scheduling of labour. The main objective for construction management is to complete a prescribed quantum of work within specified time at a previously estimated cost. In order to achieve this objective, planning is necessary. In the process of planning, one method and sequence of work is selected from various possible ways in which a project can be executed. This requires a clear definition of all activities that have to be carried out in order to complete the work.

\subsection{Resource Management}

Resource management is the efficient and effective deployment of an organization's resources when they are needed. There are five types of resource management which are necessary for the success of project. But in this study we study only labour management, because now a day's it is observed that labour problem is continuously goes on increasing. We know that manpower contributes the $30 \%$ to $50 \%$ from total cost of project. Also it is observed that manpower absenteeism rate is increases day by day. If the labours are absent the activity which is assign by these labours will automatically delayed and due to which time duration of the project gets increases and simultaneously cost increases.

\section{LABOUR MANAGEMENT THROUGH PERT}

\section{ANALYSIS}

The aim of this study is to get the optimum duration for the project and minimum cost to complete the project. Planning a project usually involves dividing it into a number of small tasks that can be assigned to individuals or teams. The project's schedule depends on the duration of these tasks and the sequence in which they are arranged. This sequence can be driven by several factors: customer deadlines, availability of personnel or resources, and dependencies among tasks. If by any reason the schedule of project get disturbed it directly affects the project completion time and project cost. So the effective utilization of resources is necessary for obtaining the optimum solution.

\subsection{Data Collection from Sites}

Data collection from the site is very important phase for any type of project. In this study the data is collected from mass housing construction project. The data is collected in the following format

* Name of construction project.

* Type of construction.

* Type of building.

* Block type.

* Total number of blocks.

* Expected completion time of project in days

* Total plot area for one block

* Total quantity of project

* Skilled and unskilled labour required to complete the project

* Optimistic, pessimistic and most likely time to complete each activity of project.

\subsection{Analysis of Collected Data}

Table -1: Total Quantity of Labour Required for Completing Project

\begin{tabular}{|l|l|l|l|}
\hline $\begin{array}{l}\text { Sr. } \\
\text { No. }\end{array}$ & Component & $\begin{array}{l}\text { Skilled } \\
\text { labour hour }\end{array}$ & $\begin{array}{l}\text { Unskilled } \\
\text { labour } \\
\text { hour }\end{array}$ \\
\hline 1 & $\begin{array}{l}\text { Site cleaning of total } \\
\text { plot area }\end{array}$ & - & 336 \\
\hline 2 & $\begin{array}{l}\text { Excavation for } \\
\text { foundation }\end{array}$ & - & 640 \\
\hline 3 & $\begin{array}{l}\text { P.C.C. laying in } \\
\text { foundation }\end{array}$ & 200 & 360 \\
\hline 4 & Footing for column & 800 & 1680 \\
\hline 5 & Column & 1920 & 3120 \\
\hline 6 & $\begin{array}{l}\text { Backfilling } \\
\text { foundation }\end{array}$ & - & 320 \\
\hline 7 & Beam & 3680 & 7680 \\
\hline 8 & Slab & 2560 & 6080 \\
\hline 9 & Wall & 1360 & 2720 \\
\hline 10 & Doors & 1240 & - \\
\hline 11 & Windows & 1104 & - \\
\hline 12 & Flooring & 416 & 640 \\
\hline 13 & $\begin{array}{l}\text { Plastering of external } \\
\text { and internal wall }\end{array}$ & 440 & 1040 \\
\hline 14 & $\begin{array}{l}\text { Painting of external } \\
\text { and internal wall }\end{array}$ & 160 & 640 \\
\hline 15 & Finishing & 360 & 800 \\
\hline Total & 14240 & 26056 & \\
\hline & & & \\
\hline
\end{tabular}

Expected time $=($ Optimistic $+4 x$ Most likely + Pessimistic) / 6

$$
\begin{aligned}
& =(340+(4 * 421)+488) \\
& =\mathbf{4 1 9}
\end{aligned}
$$

Table -2: Pessimistic, Optimistic and Most Likely Time to Complete the Project

\begin{tabular}{|l|l|l|l|}
\hline $\begin{array}{l}\text { Sr. } \\
\text { No. }\end{array}$ & Component & $\begin{array}{l}\text { Optimistic } \\
\text { time }\end{array}$ & $\begin{array}{l}\text { Most } \\
\text { likely time }\end{array}$ \\
\hline 1 & $\begin{array}{l}\text { Site cleaning of total } \\
\text { plot area }\end{array}$ & 5 & 8 \\
\hline
\end{tabular}




\begin{tabular}{|c|c|c|c|}
\hline 2 & $\begin{array}{l}\text { Excavation } \\
\text { foundation }\end{array}$ & 5 & 6 \\
\hline 3 & $\begin{array}{l}\text { P.C.C. laying in } \\
\text { foundation }\end{array}$ & 7 & 8 \\
\hline 4 & Footing for column & 28 & 35 \\
\hline 5 & Column & 52 & 56 \\
\hline 6 & $\begin{array}{l}\text { Backfilling of } \\
\text { foundation }\end{array}$ & 5 & 8 \\
\hline 7 & Beam & 120 & 135 \\
\hline 8 & Slab & 60 & 80 \\
\hline 9 & Wall & 45 & 50 \\
\hline 10 & Doors & 15 & 20 \\
\hline 11 & Windows & 10 & 15 \\
\hline 12 & Flooring & 7 & 9 \\
\hline 13 & $\begin{array}{l}\text { Plastering of external } \\
\text { and internal wall }\end{array}$ & 10 & 12 \\
\hline 14 & $\begin{array}{l}\text { Painting of external } \\
\text { and internal wall }\end{array}$ & 12 & 18 \\
\hline 15 & Finishing & 45 & 50 \\
\hline Total & 426 & 510 & 594 \\
\hline
\end{tabular}

Table -3: Computed Project Duration

\begin{tabular}{|l|l|}
\hline Time estimates & Duration \\
\hline Optimistic time estimate & 340 \\
\hline Most likely time estimate & 421 \\
\hline Pessimistic time estimate & 488 \\
\hline Mean & 419 \\
\hline
\end{tabular}

Table -4: Required Skilled Labour Hour in Various Percentages

\begin{tabular}{|l|l|l|l|l|l|}
\hline$\%$ & Days & Actual & $75 / 25$ & $50 / 50$ & $25 / 75$ \\
\hline $10 \%$ & 355 & 14240 & 12164 & 13584 & 14004 \\
\hline $20 \%$ & 370 & 14240 & 12514 & 13994 & 14474 \\
\hline $30 \%$ & 385 & 14240 & 12865 & 14405 & 14945 \\
\hline $40 \%$ & 399 & 14240 & 13215 & 14811 & 15407 \\
\hline $50 \%$ & 414 & 14240 & 13566 & 15222 & 15878 \\
\hline $60 \%$ & 429 & 14240 & 13916 & 15632 & 16348 \\
\hline $70 \%$ & 444 & 14240 & 14266 & 16042 & 16818 \\
\hline $80 \%$ & 458 & 14240 & 14616 & 16448 & 17280 \\
\hline $90 \%$ & 474 & 14240 & 14967 & 16863 & 17759 \\
\hline
\end{tabular}

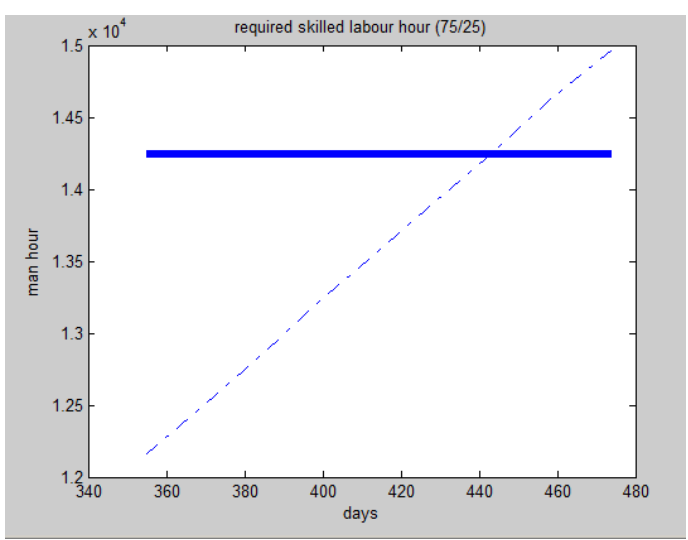

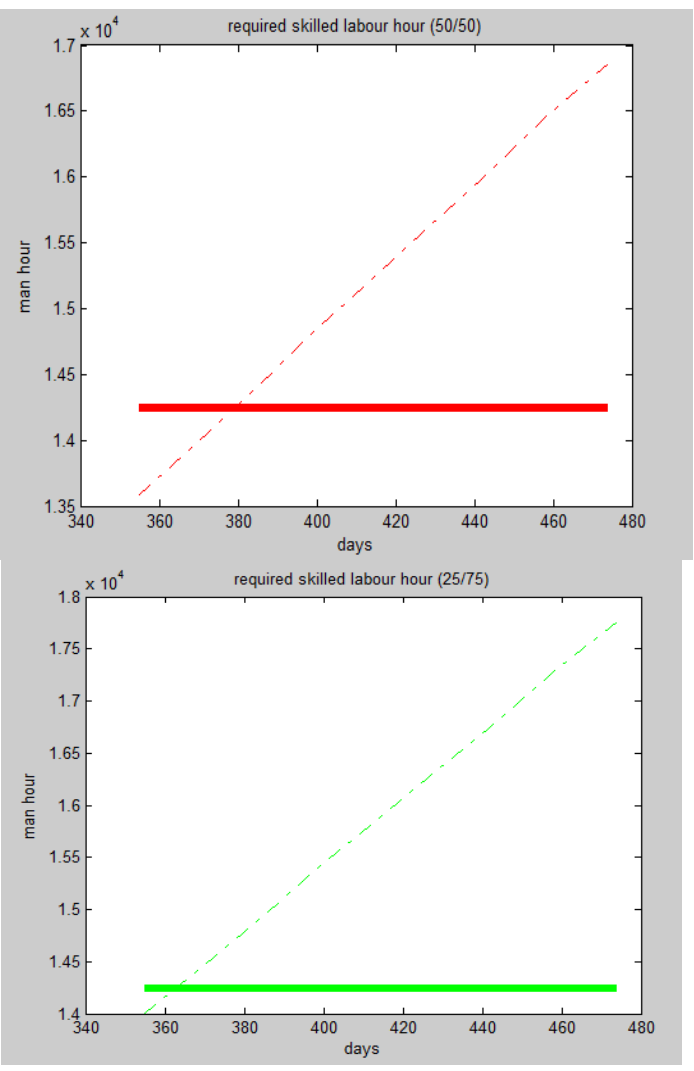

Chart -1: Skilled Labour Requirements for Various Scenarios $(2 \mathrm{BHK})$

Table -5: Cost for Skilled Labour in Various Percentages

\begin{tabular}{|l|l|l|l|l|l|}
\hline$\%$ & days & Actual & $75 / 25$ & $50 / 50$ & $25 / 75$ \\
\hline $10 \%$ & 355 & 14240 & 646425 & 721650 & 743963 \\
\hline $20 \%$ & 370 & 14240 & 665125 & 743750 & 768931 \\
\hline $30 \%$ & 385 & 14240 & 683825 & 765000 & 793953 \\
\hline $40 \%$ & 399 & 14240 & 702100 & 787100 & 818497 \\
\hline $50 \%$ & 414 & 14240 & 720800 & 808775 & 843519 \\
\hline $60 \%$ & 429 & 14240 & 739075 & 830450 & 868488 \\
\hline $70 \%$ & 444 & 14240 & 758200 & 852125 & 893456 \\
\hline $80 \%$ & 458 & 14240 & 776475 & 873800 & 918000 \\
\hline $90 \%$ & 474 & 14240 & 795175 & 895900 & 943447 \\
\hline
\end{tabular}

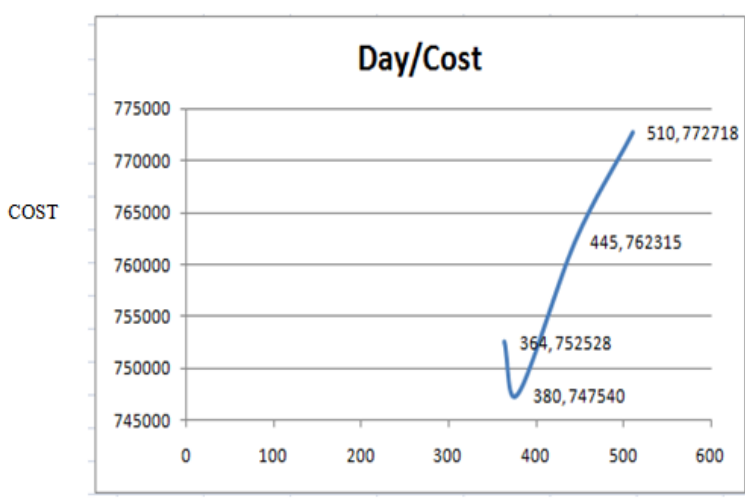

DAY

Chart -2: Project Cost for Various Scenarios (Skilled Labour for $1 \mathrm{BHK}$ ) 


\section{RESULTS AND DISCUSSION}

The study is mainly focused on the optimum duration and effective utilization of labour to improve the productivity of project. As we know that we can improve our project productivity by reducing project duration as well as project cost. There are so many methods for improving the productivity of project.

In this study we optimize the cost and project duration by effective utilization of labour. We use only labour management instead of material, machinery and any other resource management because now a day from the survey taken from various construction sites it is observed that project duration is mostly affected by labour than other resources. And for that, labour absenteeism is major reason and there are so many factors which affect the labour absenteeism and all factors are studied in literature review.

In this project for comparative study two types of blocks i.e. $1 \mathrm{BHK}$ and $2 \mathrm{BHK}$ are taken from same sites. and by analysing the collected data the optimum cost and optimum duration is found out. And then these optimum durations are comparing with the actual duration which is already estimated.

\section{CONCLUSIONS}

1. Now a day's mass housing construction projects are continuously increases in our country. And it is observed that there is delay in project duration is cause due to labour absenteeism. So to reduce the effective utilization of labour is necessary.

2. From the study of recent scenario it is observed that, now a day's Manpower are the major resources which affected the construction project scheduling. Delay in a construction scheduling because the serious effect on the cost and time. If the schedule of project is delayed then automatically the project duration is increases and if project duration increases the total cost of the project increases and therefore the productivity of the project get reduced. And it seriously affects the owner and contractor in many ways.

3. To improve the productivity of a construction industry the effective management of labour is necessary. Because now a days the absenteeism rate of the labour is increased. But the labour absenteeism is major factors which affect the productivity of project. There are so many factors that affect the labour productivity. It is observed that in mass housing constructions the effect of labour absenteeism is more, because there are so many numbers of repeated activities.

4. The absenteeism of labour is seriously affects the construction industry. The effects of absenteeism in the workplace are directly proportionate to decreased productivity. There are so many factors because of these labour are unsatisfied with their job and due to they get absent, study of causes of labour absenteeism is necessary to provide the good working environment to improve productivity of construction industry.

5. There are five types of resources used in the construction industry like manpower, machineries, money, material and space. The management of resources in a proper way is the important thing. So we studied about various types of resource management like manpower management. Money management, equipment management, material management and space management.

6. As we know that if the cost and time for the construction industry is reduce simultaneously the productivity of project is get increase. There are so many methods to find out the time duration to complete the project like PERT and CPM. But practically the project is not completed within the estimated time. There are so many factors which affect the time and cost of the project gets adversely affected.

7. From the study conducted on mass housing construction project for $1 \mathrm{BHK}$ blocks and $2 \mathrm{BHK}$ blocks it is observed that we get the optimum duration for project with minimum cost without crashing the activities. The actual duration for project was maximum.

So finally from this study I conclude that the effective utilization of labour gives the optimum duration and effective cost reduction. The crashing duration does not give the optimum solution.

To reduce the labour absenteeism rate company should take a study of labour, do discussion with labour and ask about their problem regarding absenteeism. And after understanding the labour problem tries to solve their problem and provide a good working environment for workers. If the workers are satisfied with their job and working condition they effectively perform their job and due to this the productivity of the labour will increase. Absenteeism rate becomes less. And we know that if the absenteeism rate get reduce, we can manage the labour effectively. And result of this the project is completed in optimum time.

\section{REFERENCES}

[1]. Siddesh K Pai, Mr. Satya Dheeraj, Ms. Rani Samyuktha Kristam, (2013) “ Hunan Resource Management Technique Dealing With Deficit \& Retension of Skilled Labour In Construction Industry", International Journal of Scientific And Research Publications, Volume 3, Issue 9, ISSN 22503153.

[2]. Mohamed S. Abdel-Wahab, Andrew R.J. Dainty, Stephen G. Ison, "A review of the relationship between skills and productivity in construction", Department Of Building And Civil Engineering, Loughborough University, Loughborough, UK.

[3]. Stefanie G. Brandenburg, Carl T. Hass, Keith Byrom, (2006) "Strategic Management of Human Resources in Construction", journal of management in engineering (ASCE). DOI: 10.106/(ASCE)0742-597X(2006)22.2(86) 
[4]. Nakhon kokkaew, somjintana koompai, (2012) “current practice of human resource management (HRM) in Thai construction industry: a risk and opportunity perspective", society of interdisciplinary business research, volume 1 .

[5]. S.R. De Silva, "Human Resource Management, Industrial Relations and Achieving Management Objectives", International Labour Organisation ACT/EMP Publications.

[6]. B.P.Tyagi, (2011) "Absenteeism- Cause, Effects, Remedies", Everyday Life Magazine.

[7]. S. Kamal, M. P. Venkatesh, C. Umarani, V. Senthil, (2011) "Productivity Improvement Scheduling Through Effective Resource Management", NICMAR Journal of Construction Management, Volume XXVI.

[8]. K. B .Ravindra, (2013) "Labour Welfare Practices and Social Security in Industries", International Journal of Research in Commerce, Economics and Management. Volume 3, Issue No. 6.

[9]. Dr. Renuka Rathod, Mr. Basavanth Reddy, (2012) "Employee Absenteeism: A Study at Titan Industry Limited, Banglore", The International Journal of Engineering and Science (IJES), volume 1, pp 80-84.

[10]. Mr. A. A. Attar, Prof. A. K. Gupta, Prof. D.B. Desai, "A Study of Various Factors Affecting Labour Productivity and Methods to Improve It", IOSR Journal Of Mechanical And Civil Engineering, PP 11-14.

\section{BIOGRAPHIES}

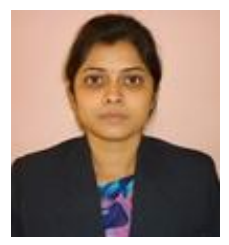

Aditi.S. Baghele, M.E (Construction Technology \& Management), B. E. Civil, Working as Assistant Professor From Last 3 years in Department of Civil engineering at S.S.G.B. College of Engineering and Technology, Bhusawal. (425203). (M.S)

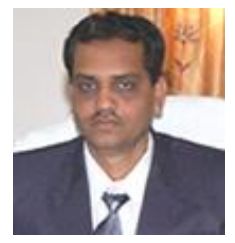

P. P.Bhangale, M.E. (Construction Management), B. E. Civil, Working as Head \& Associate Professor From Last 11 years in Department of Civil Engineering at S.S.G.B. College of Engineering and Technology, Bhusawal. (425203). (M.S)

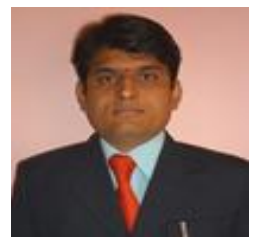

P. J. Wankhede. M.E. (Bldg.Sci.\& Tech),

B. E. Civil, Working as Assistante Professor From Last 08 years in Department of Civil Engineering at S.S.G.B. College of Egineering and Technology, Bhusawal.(425203). (M.S) 